\title{
Albanian Legal Reforms in Administrative Justice and European Integration
}

\author{
Aida Hoxha \\ PhD Candidate, University of Tirana, Faculty of Law, Department of Public Law \\ aida_hoxha08@hotmail.com
}

\section{Doi:10.5901/mjss.2013.v4n9p245}

\begin{abstract}
The administrative justice reforms are a big and continuous challenge for Albania, with the aim of having a right, fast and effective administrative judgment in the frameworks of European integration. The long-standing aspiration of Albania to be part of European Union started to be reality with the signing of Stabilization and Association Agreement entered into force in April 2009. In the same time, Albania presented its application for membership of the European Union, initiative that led Albanian Government to the commitment to focus on implementation of the key priorities set out in the European Commission Opinion and to meet all the membership criteria. One of these key priorities is the area of the rule of law and judicial reform. The aim of this study is to describe the institutional steps done from Albanian Government in administrative justice reform: the judicial reform strategy in order to ensure the independence, efficiency and accountability of actual judicial institutions, the approval and enforcement of "The Law on Administrative Courts" etc. The study is focused in the legal arguments of Administrative Court importance as the engagement of the country to improve the judicial system in administrative field, to prevent long processes in not suitable conditions, to guarantee effective protection of human rights and legitimate interests through a regular judicial process conform fast and reasonable time terms. The study gives also a clear picture of how the Administrative Court will be organized conform the "The Law on Administrative Courts" and how can be improved in order to be coherent, effective in implementation and approach of acquis communautaire.
\end{abstract}

Keywords: administrative justice, acquis communautaire, legal reforms, European Commission, administrative court

\section{Introduction}

Aministrative law is part of public law and as such is related inevitably to the decisions of government institutions. The need for administrative law comes as a result of the complexity of political, economic and social issues which can be object of conflicts between administrative bodies and citizens. ${ }^{1}$

In Albania, administrative justice is usually exercised by administrative bodies respecting the hierarchy. This means if there is a conflict between an administrative agency and a citizen, the competence to resolve the conflict belongs to the head of a high level of hierarchy of the same agency. This is the first step of the appeal. The second one is the Court of the first instance and following the Appeal and the Supreme Court.

Considering the diversity of administrative conflicts and the respect of the citizen rights for Albania came necessary the administrative justice reforms: from the administrative law reforms to the establishment of administrative courts.

The aim of this study is to describe the institutional reforms done from Albania in administrative justice system. It is mainly focused in the legal arguments of Administrative Law Reforms and Administrative Court importance to improve the judicial system in administrative field and to guarantee effective protection of human rights, to legitimate interests through a regular judicial process conform fast and reasonable time terms and as the engagement of the country to meet Copenhagen Criteria ${ }^{2}$. The study tries to give a picture of Administrative Court organization and functioning and how the "Law on Administrative Courts" is coherent and effective in implementation and approach of acquis communitaire.

\footnotetext{
1 Dobjani E. Administrative Law SHBLU, Tirana 2008

${ }^{2}$ Article 111 of the SAA requires the Albanian governemnet's objectives in relation to public administration reform to include:

-The development of a transparent open and coherent administration

-Institutional strengthening, ensuring impartial recruitment procedures, human resources management, training, e-government -the taking of measures for efficient functioning of state institutions should include both central and local administrations
} 


\section{The institutional steps done from Albanian Government in administrative justice reform}

After the communist period, the legal frameworks in Albania have been reviewed to be in accordance with democratic developments. The Administrative Law was an integral part of this change. Recommendations of the Council of Europe have been reflected in important laws in the field of public administration. ${ }^{3}$

The currently administrative law in Albania is strongly shaped from the Europian integration perspective ${ }^{4}$. The Stabilization-Association Agreement ${ }^{5}$ and several documents adopted in the integration advancement process require the country to meet the Copenhagen Criteria Public administration institutions should be able to implement the acquis communautaire, provide favorable conditions for a competitive private sector and be equipped with the institutional capacity to participate effectively in future decision-making within the Europian Union after accession.

The Constitution of Albania ${ }^{6}$ guarantees the intervention of judicial power to protect the human rights and constitutional and legal interest of the citizen. Albania is the last country in the region that has not yet Administrative Court. In the constitutional frameworks and following the continuous challenge to improve the administrative and judiciary system, Albanian government engaged to have an Administrative Court, to resolve the legal conficts between business and state administration. The establishment of this institution as part of the justice system is one of the conditions; the country must meet to join the EU.

\section{Why an Administrative Court?}

The need for judicial control of administrative activity derives by the rule of law, which is guided by the principle that the subjective rights of citizens should be protected not only toward other people but also toward public administration.

Since the rule of law is known as the base for the state organization, the principle of separation of powers would bring as result that judicial power can not and should not extend its power over administrative activity, which would interfere in the reserved area of executive power.

Administrative courts are specialized courts to resolve issues related to the exercise of public power. This is the classic definition of these organisms component of the justice system. Their role is very important because they create opportunities to guarantee and ensure that officials are working in accordance with the law, in their daily duties. Today debate about administrative courts does not focus on the fact that they should exist or not, but in terms of extending the scope of the trial and the strength or power of trials and review of administrative decisions that take these courts. Today's debates on administrative courts are focused on the role of judges in these courts and the organization of this major decision-making power to assist as much land, economy, business community and citizens.

\section{Administrative Court in Albania, a long process until the concretization: The approval, enforcement of "Law on the Organisation and Functioning of Administrative Courts and the Adjudication of Administrative Disputes" 7}

Albania is the onliest country in the region that doesn't have administrative courts. The lack of a specific link in the justice system that treated conflicts between state and business was considered reason for a difficult relation between them. The tax authorities and other state institutions have fined companies, firms or individuals. A part of penalties are refused, following the court procedures which are long and sometimes economically impossible. Interests groups like the business community have been the proposers to have administrative courts, same in EU countries.

The draft of the law "For the organization and functioning of administrative courts and the judgment of administrative conflicts" was first submited to the parliamentary Laws Committee in 2010. Since then, the draft was significantly improved as a result of public consultations with stakeholders. This law aims to reform the administrative legal framework in order to guarantee the protection of human rights and interests in a regular judiciary process. The law aims to have a fair and fast judgment toward the unfair actions that affect the interests of people from the administrative body's actions; it is considered an attempt to stop the arbitrarity and to respect the equality of the citizens or public

\footnotetext{
${ }^{3}$ Recommendation NO.R(87)16 of the Committee of Ministers to member states" On Administrative Procedures affecting a large number of persons" adopted on 17 Sept 1987

4 SIGMA-OECD, Albania General Administrative Law Framework Assessment, May 2008

${ }^{5}$ Ratified by Law No 9509 of 27.07.2006"on the ratification of the Stabilization and Association Agreement"

${ }^{6}$ Article 42/2 Albanian Constitution
}

7 Law, No.49/2012, Date: 03.05.2012, Dt.of Approval: 03.05.2012, Official Bulletin No.53, page:53 
subjects that have conflicts with administrative bodies. It is expected to strengthen the justice system of the country, improve access to justice for citizens and businesses, and facilitate faster procedural actions and trials.

The draft law on administrative courts extensively discussed was finally approved by the Albanian Parliament in 2012. It was needed a common political will from all the parties as the law required majority of the $3 / 5$ of all Parlament members $^{8}$.

The concrete object of the law is to define obligatory rules for 9 :

a) the organization and functioning of administrative courts, the status of the administrative judges;

b) jurisdiction and competence of administrative courts;

c) the principles and procedures of the trial, the parties in the process and others in administrative adjudication;

d) administrative judicial decisions and their execution;

For the first time, this law stipulates an independent judicial review that will allow for the courts' scrutiny of any legal infringement by an administrative body, including lack of competence, procedural impropriety and abuse of power.

The law sets clear criteria for selecting and further promoting administrative court judges in a transparent manner, based solely on their merits and with due regard for their qualifications, integrity, ability and efficiency. ${ }^{10}$

There are given some ideas from the theorists about the qualifications that a judge should have to be part of Administrative court. For example, the personnel and the judges should a doctorate degree and should have finished the school of Magistrates.

The law seems has solved this issue defining specific criteria like the experience as a judge, 5 years or more for the Judge of First Instance Court and 9 years or more for the Judge of Appeal Court. I agree that the experience and other criterias ${ }^{11}$ exceed the need for doctorate degree.

The law defines that: ${ }^{12}$

1-The administrative court of first instance judge with three judges all the conflicts regarding public contracts and requests made from administrative bodies for the review of administrative penalties for which the law provides the deprivation of liberty up to 30 days, as a kind of administrative punishment for the offender;

-All other disputes will be reviewed by one judge.

2. Administrative Court of Appeal has:

-Three judges, appeals against decisions of the Administrative Court of First Instance;

- 5 judges, lawsuits against normative legal act

The debate for the composition of Administrative Court has been intense because there are opinions that give the idea of deficiency in the process. It delays the process and is due to decisions taken under conditions of lack of collegiality.

The main reason why the trials in Albania deferred is the absence of the defendant in sessions. This law regulates this situation as the absence can't be a reason to terminate the case.

The law also guarantees the protection of human rights through the obligation of the public organs to prove the legitimacy of form and content of administrative action done frome them. ${ }^{13}$

With the main purpose to respect the principle of a trial within a reasonable time, the law also provides fast deadlines regarding the judgement from the Administrative Court of the first instance and the Administrative Court of Appeal in order to reduce the delay of trial processes.

The deadlines are appropriate to invest the courts with lawsuits in accordance with the social condition in the interest of the citizens. Deadlines are related closely with legal guaranty, which has a big importance because subjects actually learn how much and for how long have certain rights.

\footnotetext{
${ }^{8}$ Article 81 point 2 "a", Albanian Constitution

${ }^{9}$ Article 1 of the Law" Law on the Organisation and Functioning of Administrative Courts and the Adjudication of Administrative Disputes"

10 See the article 5 of the Law" Law on the Organisation and Functioning of Administrative Courts and the Adjudication of Administrative Disputes"

11 Article 5 of the Law "On the Organisation and Functioning of Administrative Courts and the Adjudication of Administrative Disputes"

${ }^{12}$ Article 12 of the Law "On the Organisation and Functioning of Administrative Courts and the Adjudication of Administrative Disputes"

${ }^{13}$ The burden of proof Article 35 of the Law" Law on the Organisation and Functioning of Administrative Courts and the Adjudication of Administrative Disputes"
} 
Opinions against the law have argued that it has big and real problems with legislative techniques. It is considered as a law adopted only for EU requirements and doesn't fit at all with Albanian reality. This opinion remains to be proven during the implementation of the Law.

Council of Europe and the European Convention on Human Rights have played a special role in setting standards in judicial control of public administration activity. The Council of Europe has adopted several recommendations and distribute information, documents and studies on best practices.

Another issue is the impact of the international legislation in the approval of the Administrative Courts Law. For example the legislation of Europian Convention of Human Rights, based on the decisions of the courts with law power, has influenced on legal development, especially in determining the minimum standards for judicial control of the administration, through an interpretation of Article 6 of European Convention on Human Rights and interpretation Article 13 on the implementation of effective remedies.

\section{Conclusions}

Referring the steps done, we may conclude that there has been moderate progress in completing the legal framework for judicial reform. If two years ago, the administrative court was only a plan in a draft paper, today with the will of the government and the opposite, we have an approved law that brings innovation in the judicial system. Is it enough? Although in the paper above there are given some improvements done from the law, is necessary that the approval would be accompanied with the enforcement of the law. It continues to have discussions about the way of judge's appointment, if the procedures guarantee their independence and their integrity, a big discussion is done about the lack of infrastructure to have a new specialized court in administrative issues. The progress report of Europian Commission as the main document which shows the progress of the development toward the Europian Union gives a sceptic picture of the situation. It was said that there has been moderate progress in completing the legal framework for judicial reform. Implementation of the judicial reform strategy and the relevant action plan started, albeit slowly. Budget allocation and planning, the level of human resources, and interinstitutional cooperation remain areas of concern. Albania needs to further accelerate the implementation of the judicial reform strategy in order to ensure the independence, efficiency and accountability of its judicial institutions. ${ }^{14}$

Challenges for Albanian governments continue. Overcoming the difficulties the enforcement of a new law has, is an obligation for business and community wide to have administrative courts.

That would be a guarantee for the protection of human rights and would strengthen the justice system of the country, improve access to justice for citizens and businesses.

All this is much needed for the further development of the country's judiciary.

\section{References and Legal Frameworks}

Dobjani E. (2008) Administrative Law, SHBLU, Tirana

Methasani E. Olldashi E. Public administration organs as subjects of law: time of a new approach Retrieved from http://www. unitir.academia.edu

Methasani E. Judicial control of administrative activity: analysis of the draft law "On Administrative conflicts and the organization of the administrative justice" Studime Juridike, No.2 December 2010, Law School, Tirana University

Craig, P (2003) Administrative Law, Oxford, Oxford University Press

Lorenc D. Changes while Implementing Law-reforms and Albania as a new EU candidate country

Sadushi S. (2008) Administrative Law, Ora Publishing House, Tirana

Halliday S. \& Scotty C. (2009) A Cultural Analysis of Administrative Justice, University of New South Wales Faculty of Law Research Series

Future of Administrative Justice Canadian Journal of Administrative Law \& Practice; 2008

SIGMA- OECD, (May 2008) Albania, General Administrative Law Framework Assessment,

Administrative Justice in Albania, Sigma; Support for Improvement in Governance and Management

Ad-Hoc Evaluation of the CARDS Programmes, Albania 2008

-European Commission, Albania 2012 Progress Report, Commission Staff Working Paper SEC (2012) Brussels, (10 October 2012)

Law on the Organisation and Functioning of Administrative Courts and the Adjudication of Administrative Disputes (2012)

Code of Administrative Procedures of Albania (1999)

${ }^{14}$ European Commission, Albania 2012 Progress Report, Commission Staff Working Paper SEC (2012) Brussels, (10 October 2012) 